\title{
Massurek: An Interpretation of Woman's Power
}

\author{
Uniawati \\ \{uniawati@kemdikbud.go.id\} \\ Kantor Bahasa Sulawesi Tenggara, Indonesia
}

\begin{abstract}
This paper discussed the Sangiang Serri narrative phenomenon in the massurek tradition framed in the Maddoja Bine ritual through interpretive perspectives. As a cultural expression of an agrarian Buginese society, the massurek tradition occupied a central point in the implementation of the Maddoja Bine ritual. The main problem focused on how the ideology of an agrarian Buginese society reflected through the figure of Sangiang Serri in the "Meong Palo Karellae". It presented in the massurek oral tradition. The data analyzed was surek "Meong Palo Karellae" text which told about Sangiang Serri. The analysis showed that the figure of Sangiang Serri was a metaphor that represented gender ideology in Buginese people. Women's Buginese perspective occupied a central position in building and created harmony in human relationships with God, human beings, and nature.
\end{abstract}

Keywords: Oral Tradition, Ritual, Interpretive, Massurek, Sangiang Serri

\section{Introduction}

Woman in the massurek (lontar recitation) tradition of the Buginese was presented in a different color. She was not only imaged as a tough woman, but at the same time appeared as a woman who brought her simplicity. Buginese women were women as revealed through surek texts (lontar). This paper discussed explicitly woman in the oral tradition of massurek which was carried out in the maddoja bine ritual. This ritual was an overnight ritual of staying up all night guarding rice seeds before being taken to the nursery the next day [1].

As a tradition, massurek had long been present in agrarian Buginese groups and had been passed down for generations. Thus, massurek was a cultural product of an agrarian Buginese society which not only reflected the socio-cultural life of the Buginese, but also represented an ideology. This ideology could be explored further through the contents of surek text (lontar manuscripts) presented at the maddoja bine ritual. Surek which is generally presented in the ritual was the Surek La Galigo "Meong Palo Karellae" episode which told about the adventures of Sangiang Serri (Goddess of Rice) with her escort cat to look for a suitable settlement to live in [1][2].

Amid modernity and the influence of Islamic religious beliefs, Sangiang Serri still had a special place for the supporting community. The fact could be seen through the massurek tradition that still being hold by several agrarian community groups as a series of maddoja bine rituals. The persistence of this tradition was interesting to be investigated further to understand what ideology resided behind the figure of Sangiang Serri so that the supporting community was still loyal to reveal her story in every ritual implementation. This paper tried to describe comprehensively the ideology of agrarian Buginese through massurek traditions using interpretive paradigms. 


\section{Methodology}

This research uses interpretive descriptive qualitative approach. The data is the Buginese's folktales entitled Sangiang Serri. It is about the Sangiang Serri's journey accompanied by her guards and followers in finding a suitable settlement. The story comes from the episode of La Galigo "Meong Palo Karellae" that was recorded by Nurhayati Rahman in her book "Kearifan Lingkungan Hidup Manusia Bugis".

The analysis is carried out with a careful recitation technique with an emphasis on events that revolve around the figure of Sangiang Serri. Specific events are further identified to mark the ideology reflected through various signs and metaphors. Then, the signs and metaphors representing the agrarian Buginese ideology are interpreted.

\section{Massurek Oral Traditions of the Buginese Agrarian Society}

\subsection{The Concept of Massurek Oral Traditions}

One of the most issues that frequently debated is the concept of oral tradition. Questions like what does tradition say? or another question about what is meant verbally; often the basic question that begins the explanation of the oral tradition.

First, the concept of tradition. As a word and a concept, tradition could not be avoided from ambiguity [3][4]. Therefore, Noyes from a historical point of view expressly said that tradition represented the act of transferring a practice, collection of knowledge, genre, song, whatever was sufficiently framed and structured internally to be annexed or objectified or named [3]. Meanwhile, Finnegan said that the general meaning of tradition was always associated with oral issues (word of mouth) and some vaguely interpreted it as 'habit' or 'ancient' [4].

Second, oral concepts. Referring to Amin Sweeny's explanation the phenomenon of neglect was very difficult to separate from literacy [5]. Someone who told a story orally is based on a literacy system. What the important to note in orality was a compromise between orality and textual which was generally not recognized [6].

Based on the concept of oral tradition as stated by some experts, the Massurek oral tradition could be understood as an oral tradition of agrarian Buginese society which was still practiced and contained a system of knowledge which was passed down from generation to generation. As a system of knowledge, the Massurek oral tradition represented an ideology that was expressed through surek texts recited at the Maddoja bine ritual. Massurek oral tradition as generally oral tradition functioned as a communication medium that could connect past, present, and future lives [7].

\subsection{Implementation of the Massurek Oral Tradition}

Massurek's oral tradition in the framework of this research was closely related to the Maddoja bine ritual of the agrarian Buginese community when it was about to enter the rice planting season. It was implemented at night after passing the evening light until just before dawn. The purpose of the implementation was to obtain blessings from Sangiang Serri so that the rice was protected. Then, one day farmers would harvest the abundant rice yields [1].

Before the massurek, several family heads of farmers who had kinship ties would bring their rice seeds which were ready to be sown in a house that was used as a parent. The rice seeds 
were kept near the pole which was the center of the house where the ritual was held. One of the ritual leaders called Sanro Ase ('Shaman Rice') would prepare everything for the smooth running of the ritual. With the assistance of relatives who helped carry the rice seeds, Sanro Ase would provide ritual food and other items needed during the ritual. For example, ritual food in the form of baje, sokko, and palopo; ritual objects such as incense and myrrh, lamps, and ritual leaves [1][8].

A few days before the ritual, one of the entrusted families usually contacted a passurek to be presented on the night of Maddoja Bine. This passurek would later contact the other passurek to attend together to meet the invitation by bringing along the surek text. It would be read to the ritual. At present, the existence of passurek was very rarely found. The influence of the entry of Islam was believed to be one of the causes of the decline in the interest of the young generation to study and preserve the massurek tradition. Therefore, the people who would carry out the maddoja bine ritual contacted passurek a few days before to confirm their presence.

During the massurek procession, everyone involved in the ritual sat around the passurek, the person recitation the surek text. They solemnly listened to the passurek chants that read the text "Meong Palo Karellae" in turn. The number of passurek generally consisted of 4 or more people. Alternately and continuously, they would recite the surek texts until they were finished. At the end of the surek recitation, rice seeds were ready to be brought to the fields. It wanted to be sown in the nursery.

\subsection{Story Summary "Meong Palo Karellae"}

The story of "Meong Palo Karellae" was quite legendary for the Buginese, especially those who lived in the residential areas of agrarian groups. The story was always accompanied by the existence of Sangiang Serri as a rice goddess who was believed to be a protector as well as an energy provider for the source of life of Buginese people who worked as farmers. The distribution of this story was quite extensive with various variants. However, the story "Meong Palo Karellae" found in several texts told the story of Sangiang Serri's journey along with Meong Palo Karellae moving from one village to another to find a suitable place for settlement.

The many variants of the script "Meong Palo Karellae" was not an obstacle in writing this paper. However, for the sake of the focus of this discussion, the story of "Meong Palo Karellae" which would be discussed referred to the manuscript. It had been published in Nurhayati's writings [2]. In summary, the following story would be presented "Meong Palo Karellae".

The story began when Meong Palo Karellae. It was a three-colored striped male cat. He settled in Tempe with all the calm he felt. Never once was he harassed by humans even though he ate fish belonging to his master. Finally, he made the deities in the sky not pleasing, then threw him into Maiwa, Enrekang. In this area, he felt a much different life from before. The human attitude was not friendly and tends to be rude to him. When he carried off the homeowner's fish, he was tortured with punches and cross-border treatment. This situation made Sangiang Serri pitied to see her bodyguard being treated poorly by humans who lived in the area. Then, she decided to leave the area in looking for new settlements where people live lovingly.

Sangiang Serri together with Meong Palo Karellae were followed by all types of grains. Wanderings that were not easy because they have to go through the ups and downs of hills with various human characters found in every village that was passed. Some villages that were passed were Lamuru, Soppeng (Pattojo, Mario, Tanete, Langkemme, Kessi), Mangkoso, Wettung, Lisu, and ended at Barru. It was in this area that Sangiang Serri decided to invite Meong Palo Karellae and her other followers to settle down after seeing the community life in the village 
harmoniously. Since living in the village, Sangiang Serri gave much advice to the public about how to behave and speak well. What do not and do allow to be done in creating a prosperous and respectful life.

\subsection{Sangiang Serri and the Gender Ideology of Agrarian Buginese}

The issue of ideology was often understood as a construction of meaning related to the power. Such an ideological concept proposed by Fairclough that the system of meaning contained through language was always supported by power [9]. However, the ideology intended here was quite specific when it was theoretically defined. Ideology could simply be understood as a belief system [10]. Within this framework of understanding, ideology contained representations that explained the identity of a group with their shared beliefs [11].

The massurek tradition was a representation of the identity of an agrarian Buginese society that included a belief system. Surek texts was contained a metaphor and symbol that had meaning. The presence of metaphors and symbols were not just born, but deliberately constructed to convey a message through language media. It was communicated orally. Through language as well, the ideology of the Buginese would be able to be read by understanding the meaning of metaphors and symbols contained in the surek text.

An understanding of the meaning of metaphors and symbols found in surek texts was carried out based on the interpretive paradigm. This was based on the basic assumption that humans were beings who could create and used symbols to communicate with each other [12]. Based on that assumption, it was believed that the presence of surek text in an agrarian Buginese society was a form of communication that contained a certain ideology that was intended to be conveyed to the recipient of the message. Thus, to simplify the interpretation of surek texts, it was very important to recognize the metaphors and symbols that dominated the contents of the text.

In surek text, there was one metaphor that was dominantly present as the basis for telling the overall contents of the text. The word Sangiang Serri in the surek text does not merely feature a sacred figure representing the beliefs of the Bugis towards supernatural beings. Sangiang Serri in the socio-cultural context of the Buginese community was a metaphor whose presenced contains an ideology about gender. She was a woman who had power and other features that accompanied her.

First, having the ability to escape from an act of oppression. Sangiang Serri's decision to leave Maiwa represented the power of women to oppose the forms of oppression that placed them as objects. The violence received by her loyal bodyguard Meong Palo Karellae was enough to make Sangiang Serri realized that other human beings had behaved arbitrarily. She rejected all forms of violence committed against her group. The rejection was shown by going out of the domestic arena into the public sphere through a long wandering. The various incidents she encountered during her wandering were not an easy matter for a woman. However, it could be passed with the power it had.

Sangiang Serri's wandering discourse found in the surek text opened a space for community thinking that women also had the same freedom as men to be in the public sphere. This discourse talked about the gender ideology of an agrarian Buginese society that was neglected to understand before. The stereotype of the Buginese was so embedded as a group of seafarers as well as followers of patriarchy who place men as subjects over women. This surek text spoke differently. Through the Sangiang Serri metaphor, this text showed quite clearly that women in the Buginese society were privileged at the same time as seen as having the power to 
protect the earth from human arbitrary behavior. In another sense, women had their arenas on the land, while men on the sea.

Second, knowing what she wanted. The Sangiang Serri character told in the surek text was very understated. She did not like quarrels or disagreement, both in the family and fellow communities. She was also not impressed with the attitude of humans who did not appreciate God's gifts, such as wasting food. The Sangiang Serri character displayed in the surek text as a whole reflected a concern for nature. She wanted humans to have a positive attitude towards nature by respecting and giving thanks for everything that was obtained through nature.

Mutual respect, love, and good at gratitude for God's gift were the attitude sought by Sangiang Serri in her wandering. Such an attitude was not easy to find until she continued to wander from one village to another with a strong determination. Although it was not an easy. In the end, she found a village that seem like she had imagined before. The people lived in harmony, peace, love, and are grateful. This portrait did not merely describe how the life of a certain group of people was. Behind that, there was a meaning supported by the ideology of an agrarian Buginese society that a woman must be aware of and understand herself. To have equal relationships with men, women must know what they wanted so that they could appear as subjects. Women's freedom from oppression depended on their ability to reflect on themselves until they were fully aware that they were "valuable".

Third, give a positive influence on others. The advice given by Sangiangseri to the community was used as a way of life for society. She could appear as a subject that gave awareness to humans to understand their existence. Its presence in the middle of society at the same time free up their thinking about life which oppresses one another. The act of oppression did not only occur between humans, but also against nature. This showed that women had a vital role in the balance of human life with God, humans with humans, and humans with nature. Because of this important role, women must be respected as awards were given to men.

Gender ideology that wrapped surek texts showed a construction of Buginese thought which viewed women as having the right to play roles outside the domestic sphere. Buginese people who lived in an agrarian environment had the view that the public sphere did not only belong to men, but women also had the right to be in that space. The Sangiang Serri metaphor quite clearly represented how she appeared as a woman who had a positive influence on the life around her.

\section{Conclusion}

The gender ideology represented through the Sangiang Serri metaphor in the surek text showed that there was another side that had been neglected by the public so far. That the Buginese were always stereotyped as accomplished sailors in which men played a central role. It apparently in other arenas women also played a quite important role. The story of "Meong Palo Karellae" presented in the oral tradition of the agrarian Buginese people revealed the role and position of women in the public sphere. Women and men had equal relations as partners who played roles based on their respective arenas. The gender ideology embodied in the Sangiang Serri metaphor need to be contemplated that women's voices shouting equality between men and women did not only emerge around the end of the 18th century when the feminist movement began to be called out openly. Long before that, gender ideology had been found through the oral traditions of the people. One of them is the oral tradition of massurek. 


\section{References}

[1] A. Sulkarnaen, "Kelanjutan Tradisi Lisan Maddoja Bine dalam Konteks Perubahan Sosial Masyarakat Bugis,” Masy. Indones., vol. 43, no. 2, pp. 261-274, 2017.

[2] N. Rahman, Kearifan Lingkungan Hidup Manusia Bugis. Makassar: La Galigo Press, 2009.

[3] R. Finnegan, "Tradition, But What Tradition and For Whom," Oral Tradit., vol. 6, no. 1, pp. 104$124,1991$.

[4] D. Noyes, "Tradition: Three Traditions," J. Folk. Res. An Int. J. Folk. Ethnomusicol., vol. 46, no. 3, pp. 233-268, 2009.

[5] A. Sweeney, "Surat Naskah Angka Bersuara: ke Arab Mencari 'Kelisanan,"” in Metodologi Kajian Tradisi Lisan, M. P. S. S. Pudentia, Ed. Jakarta: Yayasan Pustaka Obor Indonesia, 2015, pp. 96-119.

[6] W. Cariou, "Life-telling: Indigenous Oral Autobiography and the Performance of Relation," Biography, vol. 39, no. 3, pp. 314-327, 2016.

[7] E. M. Sone, "African Oral Literature and the Humanities: Challenges and Prospects," Humanities, vol. 7, no. 3, pp. 1-20, 2018.

[8] Nasruddin, "Tradisi Mappamula (Panen Pertama) pada Masyarakat Bugis Tolotang di Sidenreng Rappang (Kajian Antropologi Budaya," Rihlah, vol. 5, no. 1, pp. 1-15, 2017.

[9] N. Fairchlough, Discourse and Social Change. Cambridge: Polity Press, 2006.

[10] T. A. Van Dijk, "Ideology and Discourse Analysis," J. Polotical Ideol., vol. 11, no. 2, pp. 115140, 2006.

[11] W. Udasmoro, "Pengantar," in Hamparan Wacana dari Praktik Ideologi, Media Hingga Kritik Poskolonial, W. Udasmoro, Ed. Yogyakarta, 2018, pp. vi-xxv.

[12] H. S. Ahimsa-Putra, "Peringatan, Cobaan, dan Takdir: Politik Tafsir Bencana Merapi"," Masy. Indones., vol. 26, no. 1, pp. 27-53, 2000. 